\title{
A Statistical Approach for Optimization of Simultaneous Production of $\beta$-Glucosidase and Endoglucanase by Rhizopus oryzae from Solid-State Fermentation of Water Hyacinth Using Central Composite Design
}

\author{
Moumita Karmakar and Rina Rani Ray \\ Microbiology Laboratory, Department of Zoology, Molecular Biology \& Genetics, Presidency University, 86/1, \\ College Street, Kolkata, 700 073, India \\ Correspondence should be addressed to Rina Rani Ray, rina_ray64@yahoo.co.in
}

Received 8 March 2011; Revised 6 April 2011; Accepted 7 April 2011

Academic Editor: Triantafyllos Roukas

Copyright (c) 2011 M. Karmakar and R. R. Ray. This is an open access article distributed under the Creative Commons Attribution License, which permits unrestricted use, distribution, and reproduction in any medium, provided the original work is properly cited.

The production cost of $\beta$-glucosidase and endoglucanase could be reduced by using water hyacinth, an aquatic weed, as the sole carbon source and using cost-efficient fermentation strategies like solid-state fermentation (SSF). In the present study, the effect of different production conditions on the yield of $\beta$-glucosidase and endoglucanase by Rhizopus oryzae MTCC 9642 from water hyacinth was investigated systematically using response surface methodology. A Central composite experimental design was applied to optimize the impact of three variables, namely, substrate concentration, $\mathrm{pH}$, and temperature, on enzyme production. The optimal level of each parameter for maximum enzyme production by the fungus was determined. Highest activity of endoglucanase of $495 \mathrm{U} / \mathrm{mL}$ was achieved at a substrate concentration of $1.23 \%, \mathrm{pH} 7.29$, and temperature $29.93^{\circ} \mathrm{C}$ whereas maximum $\beta$-glucosidase activity of $137.32 \mathrm{U} / \mathrm{ml}$ was achieved at a substrate concentration of $1.25 \%, \mathrm{pH} 6.66$, and temperature $32.09^{\circ} \mathrm{C}$. There was a direct correlation between the levels of enzymatic activities and the substrate concentration of water hyacinth as carbon source.

\section{Introduction}

Cellulose being an abundant and renewable resource is a potential raw material for the microbial production of food, fuel, and chemicals [1]. The bioconversion of cellulosic materials has been receiving attention in recent years. Complete enzymatic hydrolysis of enzymes requires synergistic action of three types of enzymes, namely, cellobiohydrolase, endoglucanase, and $\beta$-glucosidase [2]. The high cost of production of these enzymes has hindered the industrial application of cellulose bioconversion [3]. Production cost of cellulases may be brought down by multifaceted approaches which include the use of cheap lignocellulosic substrates for fermentation production of the enzyme, the use of costefficient fermentation strategies like solid-state fermentation (SSF) [4] as the use of SSF as a production method of enzymes could offer some apparent economic and engineering advantages over the classical submerged fermentation $(\mathrm{SmF})[5,6]$, and the optimization of the key factors of the fermentation process.

Large quantities of cellulosic wastes are generated everyday through forestry and agricultural processes [7] which remain unutilized and accumulate as wastes in the environment thereby causing pollution problem [8]. Water hyacinth (Eichornia crassipes) is one of the fastest growing aquatic weeds that causes huge economic loss by impeding water flow, accelerating water evaporation, increasing mosquito breeding, and destroying rice fields [9].The approach of utilizing water hyacinth for cellulase production was expected to serve the twin function of otherwise nuisance weeds as well as reduction of enzyme cost [10]. Being a microphyte and rich in cellulose content, it could be used as the sole carbon 
source in the culture medium [11] and as feedstock for fermentable sugar production by enzymatic hydrolysis [12]. Further, the optimization of the fermentative conditions involving determination of the cumulative effect of multiple parameters regulating the rate of enzyme production might employ response surface methodology, as it was found to be more satisfactory and effective than other methods such as classical one-at-a-time or mathematical methods due to its efficacy to study many variables simultaneously with a low number of observations, saving time and costs $[13,14]$.

Although a number of well-studied fungal strains were reported to have cellulolytic activities $[7,15,16]$, extensive search is still going on to isolate a hyperproducing microbial strain that could be used for bulk production of cellulases at a nominal cost.

The aim of the present work was to optimize the conditions for simultaneous production of extra cellular $\beta$ glucosidase and endoglucanase by the hyperproducing strain of Rhizopus oryzae in a cost-effective and ecofriendly way. On the basis of results obtained from "one-variable-at-a-time" experiment, $\mathrm{pH}$, temperature, and substrate concentration were selected for response surface methodology studies, and a central composite design (CCD) was designed to get the optimum level of these three factors to maximize the $\beta$-glucosidase and endoglucanase production from SSF of water hyacinth.

\section{Materials and Methods}

2.1. Micro-Organism. Rhizopus oryzae, PR7 MTCC 9642 [17], was isolated from the decaying vegetation enriched soil of India. The strain was identified by and deposited to Microbial Type Culture Collection, India.

2.2. Chemicals. All chemicals used were of analytical grade. Water hyacinth (Eichornia crassipes) foliage was collected, dried at $60^{\circ} \mathrm{C}$ for 12 hours, and pulverized before supplementing in the culture media.

2.3. Pretreatment of the Substrate. Water hyacinth (Eichornia crassipes) foliage was collected, oven-dried at $60^{\circ} \mathrm{C}$ for 12 hours, pulverized, and pretreated with steam explosion by double autoclaving before using as substrate in the culture media.

2.4. Cultivation of the Strain. The strain was cultivated in $100 \mathrm{ml}$ Erlenmeyer flasks each containing $20 \mathrm{~mL}$ Basal Medium (BM) composed of $\left(\mathrm{gL}^{-1}\right)$ : peptone 0.9; $\left(\mathrm{NH}_{4}\right)_{2} \mathrm{HPO}_{4} \quad 0.4 ; \mathrm{KCl} 0.1 ; \mathrm{MgSO}_{4} \cdot \mathrm{H}_{2} \mathrm{O} 0.1$ and carboxy methyl cellulose 0.5 at $\mathrm{pH} 6$ and temperature $37^{\circ} \mathrm{C}$ for $48 \mathrm{hrs}$ in static condition. For SSF, the strain was cultured similarly in $100 \mathrm{~mL}$ Erlenmeyer flasks containing totally dried water hyacinth dust $(10 \mathrm{mg}$ ) and salts (based on $10 \mathrm{~mL}$ medium) moistened with $0.5 \mathrm{~mL}$ distilled water, making the net moisture content $5 \%$. Likewise, the moisture content was kept constant and did not vary with variation of substrate concentration.
TABle 1: Process variables and their levels.

\begin{tabular}{lcccccc}
\hline Independent variables & Symbol & \multicolumn{5}{c}{ Code levels } \\
\hline & & $-\mathbf{a}$ & $-\mathbf{1}$ & $\mathbf{0}$ & $+\mathbf{1}$ & $+\mathbf{a}$ \\
Substrate conc. (\%,w/w) & $\mathrm{A}$ & 0.24 & 0.5 & 0.87 & 1.25 & 1.50 \\
$\mathrm{pH}$ & $\mathrm{B}$ & 4.97 & 6 & 7.5 & 9 & 10.02 \\
Temperature & $\mathrm{C}$ & 10.50 & 18 & 29 & 40 & 47.49 \\
\hline
\end{tabular}

2.5. Enzyme Extraction and Enzyme Assay. The grown culture was filtered through filter paper (Whatman No 1), filtrate was centrifuged at $10,000 \mathrm{rpm}$ for $5 \mathrm{~min}$ at $4^{\circ} \mathrm{C}$, and the supernatant was used as the crude enzyme. To measure the activity of $\beta$-glucosidase and endoglucanase, tubes containing the assay mixture $(1 \mathrm{~mL})$ each containing an $0.5 \mathrm{ml}$ of enzyme diluted with $0.1(\mathrm{M})$ phosphate buffer $(\mathrm{pH} 6)$ were incubated with $1 \%(\mathrm{w} / \mathrm{v})$ salicin for 15 minutes and $1 \%(\mathrm{w} / \mathrm{v})$ $\mathrm{CM}$-cellulose for 10 minutes [18], respectively, at $33^{\circ} \mathrm{C}$. The reducing sugar released in either case was measured by the dinitrosalicylic acid method [19] taking glucose as standard. Blanks were prepared with inactivated enzymes. One unit of $\beta$-glucosidase and endoglucanase was defined as that amount of enzyme that liberated $1 \mu$ mole of glucose per ml per minute of reaction.

2.6. Optimization of Parameters. Various factors like (water hyacinth) substrate concentration (A), $\mathrm{pH}(\mathrm{B})$, and cultivation temperature $(\mathrm{C})$ were tested by varying the determining factor. Each experiment was carried out in triplicate and their values were averaged.

2.7. Statistical Analysis. An evaluation copy of the statistical software, Design-Expert version 7.1.6, from Stat-Ease, Inc., Minn, USA was used for analysis of experimental data and to plot response surface. ANOVA was used to estimate the statistical parameters.

\section{Results and Discussion}

3.1. Detection of the Effects of Substrate Concentration, Temperature, and $\mathrm{pH}$ for Optimum Enzyme Production by RSM. To detect the effect of three major key factors responsible for enzyme production, each factor in the design was studied at five different levels $(-\alpha,-1,0,+1,+\alpha)$ (Table 1$)$ by central composite design. The minimum and maximum ranges of variables were investigated, and the full experimental plan with respect to their values in actual form was listed in Table 1. Upon completion of experiments, the average maximum enzymatic activity was taken as the dependent variable or response (Y). A second-order polynomial equation was then fitted to the data by a multiple regression procedure. This resulted in an empirical model that related the responses measured to the independent variables of the experiment. For a three-factor system, the model equation was taken to be

$$
\begin{aligned}
Y= & \beta_{0}+\beta_{1} A+\beta_{2} B+\beta_{3} C+\beta_{11} A_{2}+\beta_{22} B_{2}+\beta_{33} C_{2}+\beta_{12} A B \\
& +\beta_{23} B C+\beta_{13} A C,
\end{aligned}
$$


TABLE 2: Experimental design of central composite design.

\begin{tabular}{|c|c|c|c|c|c|c|c|}
\hline \multirow[t]{2}{*}{ Std order } & \multirow[t]{2}{*}{ Sub conc } & \multirow[t]{2}{*}{$\mathrm{pH}$} & \multirow[t]{2}{*}{ Temp. } & \multicolumn{2}{|c|}{$\beta$-glucosidase production } & \multicolumn{2}{|c|}{ Endoglucanase production } \\
\hline & & & & Actual value & Predicted value & Actual value & Predicted value \\
\hline 1 & 0.5 & 6 & 18 & $50 \pm 3$ & 46.07 & $250 \pm 17.32$ & 198.91 \\
\hline 2 & 1.25 & 6 & 18 & $100 \pm 3$ & 104.46 & $325 \pm 20.22$ & 310.48 \\
\hline 3 & 0.5 & 9 & 18 & $16.66 \pm 1$ & 7.03 & $25 \pm 2$ & 22.93 \\
\hline 4 & 1.25 & 9 & 18 & $33.33 \pm 2.94$ & 40.42 & $250 \pm 10$ & 259.50 \\
\hline 5 & 0.5 & 6 & 40 & $83.32 \pm 3.25$ & 75.46 & $250 \pm 14$ & 236.04 \\
\hline 6 & 1.25 & 6 & 40 & $116.65 \pm 4.23$ & 125.51 & $350 \pm 3$ & 347.61 \\
\hline 7 & 0.5 & 9 & 40 & $50 \pm 3.6$ & 44.77 & $25 \pm 2$ & 35.06 \\
\hline 8 & 1.25 & 9 & 40 & $66.6 \pm 1.96$ & 69.82 & $225 \pm 12.58$ & 271.63 \\
\hline 9 & 0.24 & 7.5 & 29 & $50 \pm 2$ & 65.46 & $150 \pm 6.245$ & 181.76 \\
\hline 10 & 1.50 & 7.5 & 29 & $150 \pm 13.22$ & 135.61 & $500 \pm 24.24$ & 474.51 \\
\hline 11 & 0.87 & 4.9 & 29 & $83.3 \pm 1.12$ & 82.01 & $175 \pm 5.56$ & 221.57 \\
\hline 12 & 0.87 & 10.0 & 29 & $0 \pm 0$ & 2.36 & $50 \pm 4.3$ & 9.71 \\
\hline 13 & 0.87 & 7.5 & 10.5 & $33.33 \pm 1.15$ & 34.14 & $175 \pm 6.55$ & 207.43 \\
\hline 14 & 0.87 & 7.5 & 47.5 & $83.32 \pm 1.5$ & 83.57 & $275 \pm 13.74$ & 248.85 \\
\hline 15 & 0.87 & 7.5 & 29 & $116.65 \pm 0.56$ & 116.61 & $450 \pm 22.91$ & 449.82 \\
\hline 16 & 0.87 & 7.5 & 29 & $116.65 \pm 2.05$ & 116.61 & $450 \pm 17.32$ & 449.82 \\
\hline 17 & 0.87 & 7.5 & 29 & $116.65 \pm 3.02$ & 116.61 & $450 \pm 19.92$ & 449.82 \\
\hline 18 & 0.87 & 7.5 & 29 & $116.65 \pm 1.02$ & 116.61 & $450 \pm 21.79$ & 449.82 \\
\hline 19 & 0.87 & 7.5 & 29 & $116.65 \pm 0.73$ & 116.61 & $450 \pm 20.95$ & 449.82 \\
\hline 20 & 0.87 & 7.5 & 29 & $116.65 \pm 1.07$ & 116.61 & $450 \pm 10$ & 449.82 \\
\hline
\end{tabular}

where $Y$ is the predicted response, $\beta_{0}$ is the intercept, $\beta_{1}, \beta_{2}, \beta_{3}$ are linear coefficients, $\beta_{11}, \beta_{22}, \beta_{33}$ are squared coefficients, and $\beta_{12}, \beta_{23}, \beta_{13}$ interaction coefficients and $\mathrm{A}$ denoted substrate concentration $(\% \mathrm{w} / \mathrm{v}), \mathrm{B}$ was the $\mathrm{pH}$, and $\mathrm{C}$ was the temperature $\left({ }^{\circ} \mathrm{C}\right)$. The responses of the $\mathrm{CCD}$ design were fitted with a second-order polynomial equation.

The CCD contained a total of 20 experimental trials that included 14 trials for noncentral points and 6 trials for replications of the central points. Concentration ranges of the three components used in central composite design was shown (Table 2).

3.2. Factors Affecting the $\beta$-glucosidase Production. On the basis of quadratic polynomial equation of response surface model (1), the present model and data analysis not only allowed us to define optimum conditions for $\beta$-glucosidase production but also showed combined effect of independent variables such as substrate concentration $(\mathrm{w} / \mathrm{v}), \mathrm{pH}$, and temperature in terms of coded factors in (2)

$\beta$-glucosidase production (X)

$$
\begin{aligned}
= & +116.62+20.86 * \mathrm{~A}-23.68 * \mathrm{~B}+14.70 * \mathrm{C} \\
& -6.25 * \mathrm{~A} * \mathrm{~B}-2.08 * \mathrm{~A} * \mathrm{C}+2.09 * \mathrm{~B} * \mathrm{C} \\
& -5.69 * \mathrm{~A}^{2}-26.32 * \mathrm{~B}^{2}-20.42 * \mathrm{C}^{2},
\end{aligned}
$$

where response $(\mathrm{X})$ was the $\beta$-glucosidase activity $(\mathrm{U} / \mathrm{mL})$ and $\mathrm{A}, \mathrm{B}$, and $\mathrm{C}$ denoted substrate concentration $(\mathrm{w} / \mathrm{v}), \mathrm{pH}$, and temperature $\left({ }^{\circ} \mathrm{C}\right)$, respectively.
The statistical significance of (2) was checked by $F$ test, and the analysis of variance (ANOVA) for the response surface quadratic model is shown in Table 3. It was evident that the model was highly significant, as suggested by the model $F$ value and a low probability value $(P$ model $>F)$. The coefficient of variation $(\mathrm{CV})$ indicated the degree of precision with which the treatments were compared. As the higher value of $\mathrm{CV}$ indicated the lower reliability of the experiment, in the present case, a lower value of CV (11.13) indicated a better precision and reliability of the experiments [20]. The precision of a model could be checked by the determination coefficient $(R 2)$ and correlation coefficient $(R)$. The determination coefficient $(R 2)$ implied that the sample variation of $97.5 \%$ for $\beta$-glucosidase production was attributed to the independent variables, and only about $2.5 \%$ of the total variation could not be explained by the model. Normally, a regression model having an $R 2$ value higher than 0.9 was considered to have a very high correlation [21]. Here, the value of $R(0.9525)$ for (2) indicated a close agreement between the experimental results and the theoretical values predicted by the model equation. The natural logarithm (ln) of the residual SS (sum of square) against lambda was one, dip suddenly with a minimum in the region of the best optimum value 0.84 (Figure 1(a)). The data did not require a transformation, as current value of confidence interval (lambda) was very close to the optimum value [22]. The model showed the minimum and maximum confidence interval value of 0.56 and 1.18, respectively (Figure 1(a)). Three dimensional response surface plots graphically represented regression equations and were generally used to demonstrate relationships between the 


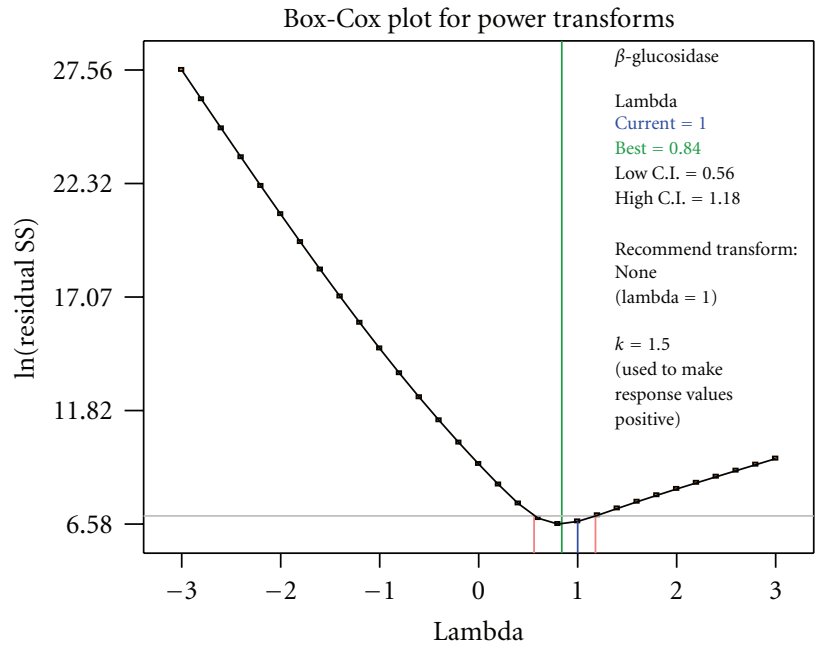

(a)

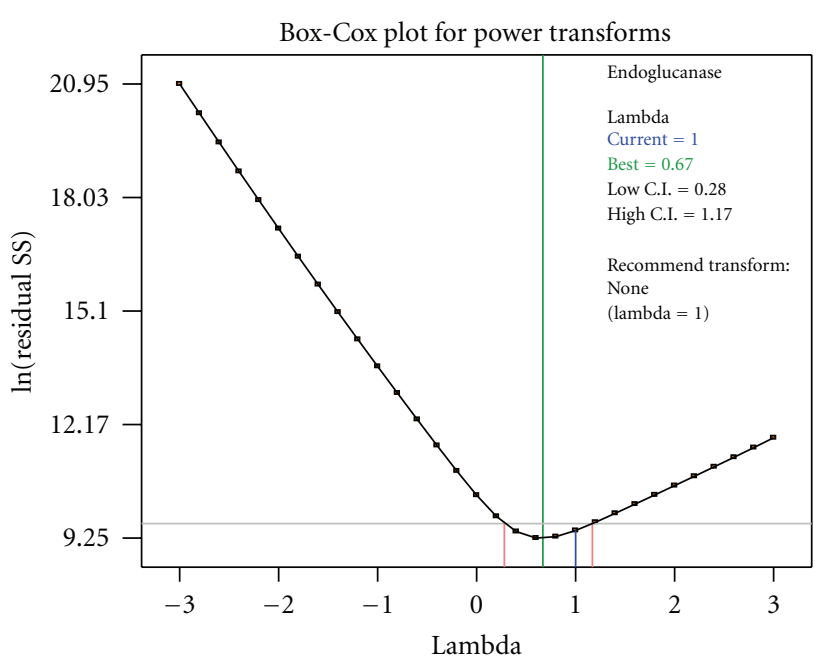

(b)

Figure 1: (a)Box-Cox plot for power transforms for $\beta$-glucosidase production. (b) Box-Cox plot for power transforms for endoglucanase production.

TABLE 3: Analysis of variance for $\beta$-glucosidase production.

\begin{tabular}{|c|c|c|c|c|c|c|}
\hline Source & Sum of squares & $\mathrm{df}$ & Mean square & $F$ value & $P$ value & Prob $>F$ \\
\hline Model & 31558.5 & 9 & 3506.5 & 43.3151 & $<.0001$ & significant \\
\hline A: sub. conc & 5940.86 & 1 & 5940.86 & 73.3863 & $<.0001$ & \\
\hline B-pH & 7658.88 & 1 & 7658.88 & 94.6087 & $<.0001$ & \\
\hline C: temp & 2949.85 & 1 & 2949.85 & 36.4389 & .0001 & \\
\hline $\mathrm{AB}$ & 312.5 & 1 & 312.5 & 3.86025 & .0778 & \\
\hline $\mathrm{AC}$ & 34.7778 & 1 & 34.7778 & 0.4296 & .527 & \\
\hline $\mathrm{BC}$ & 34.8613 & 1 & 34.8613 & 0.43063 & .5265 & \\
\hline $\mathrm{A}^{2}$ & 465.899 & 1 & 465.899 & 5.75517 & .0374 & \\
\hline $\mathrm{B}^{2}$ & 9980.03 & 1 & 9980.03 & 123.282 & $<.0001$ & \\
\hline $\mathrm{C}^{2}$ & 6009.27 & 1 & 6009.27 & 74.2314 & $<.0001$ & \\
\hline
\end{tabular}

$\mathrm{R}^{2}-0.975$, Adj $\mathrm{R}^{2} 0.9525$, Pred $\mathrm{R}^{2}-0.8083$, C.V. $\%-11.13$.

response and experimental levels of each variable (Figures 2(a), 2(b), and 2(c)).

3.3. Factors Affecting the Endoglucanase Production. For SSF (3), the response (endoglucanase production $\mathrm{U} / \mathrm{mL}$ ) of the CCD design was fitted with a quadratic equation

Endoglucanase production (Y)

$$
\begin{aligned}
= & +449.82+87.04 * \mathrm{~A}-2.99 * \mathrm{~B}+12.31 * \mathrm{C} \\
& +31.25 * \mathrm{~A} * \mathrm{~B}+0.000 * \mathrm{~A} * \mathrm{C}-6.25 * \mathrm{~B} * \mathrm{C} \\
& -43.02 * \mathrm{~A}^{2}-118.15 * \mathrm{~B}^{2}-78.37 * \mathrm{C}^{2},
\end{aligned}
$$

where $\mathrm{Y}$ denoted the predicted responses of the endoglucanase production in SSF and A, B, and C denoted substrate concentration $(\mathrm{w} / \mathrm{v}), \mathrm{pH}$, and temperature $\left({ }^{\circ} \mathrm{C}\right)$, respectively.

The statistical significance of the model equation evaluated by analysis of variance (ANOVA) showed that the model
$F$ value for endoglucanase production was 39.13 ; that is, the model was statistically significant [23]. In this case, values of "Prob > F" less than 0.05 for A, B, AB, $\mathrm{A}^{2}, \mathrm{~B}^{2}, \mathrm{C}^{2}$ (Table 4) indicated that model terms were significant [24].The model showed the minimum and maximum confidence interval value of 0.28 and 1.17, respectively, (Figure 1(b)) and a high correlation $(\mathrm{R} 2=0.9724)$ between the predicted and experimental values. Three-dimensional response surface plots graphically represented regression equations and were generally used to demonstrate relationships between the response and experimental levels of each variable in case of endoglucanase production (Figures 3(a), 3(b), and 3(c)). These surface plots, therefore, allowed for visualization of the optimum levels of each variable for the maximum production of the endoglucanase enzyme.

3.4. Validation of the Model. The statistical optimal values of variables were obtained where the central composite design and the response at the different points yielded maximum $\beta$ glucosidase and endoglucanase in SSF. A repeat fermentation 


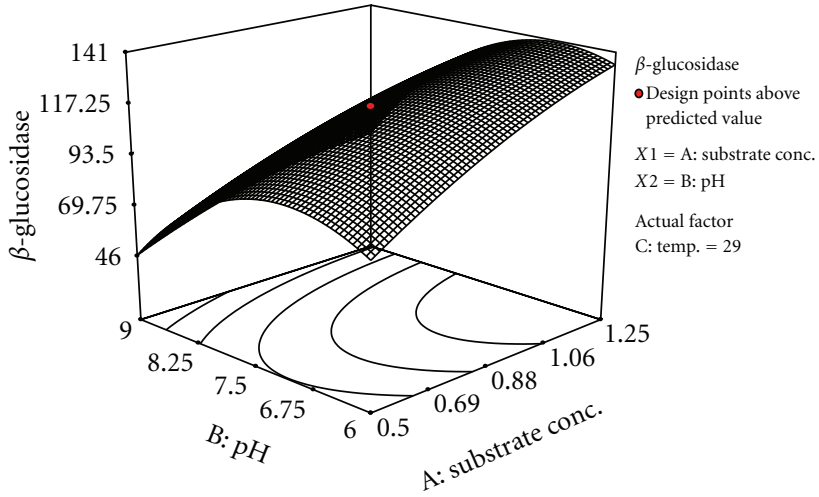

(a)

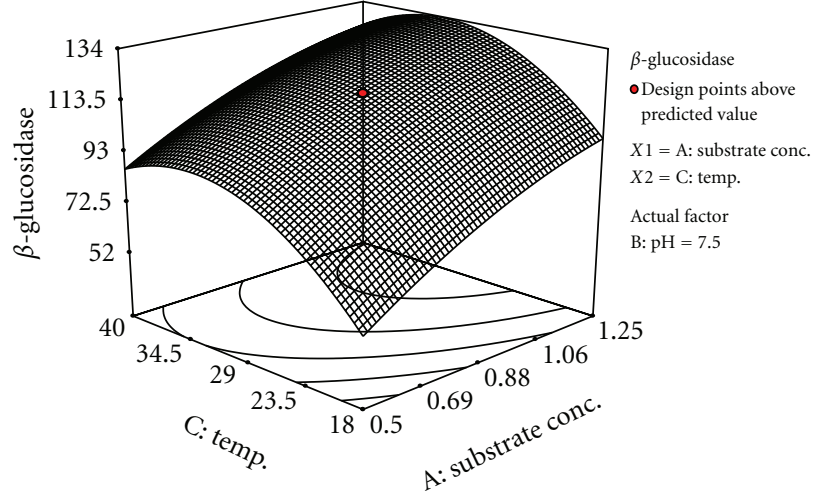

(b)

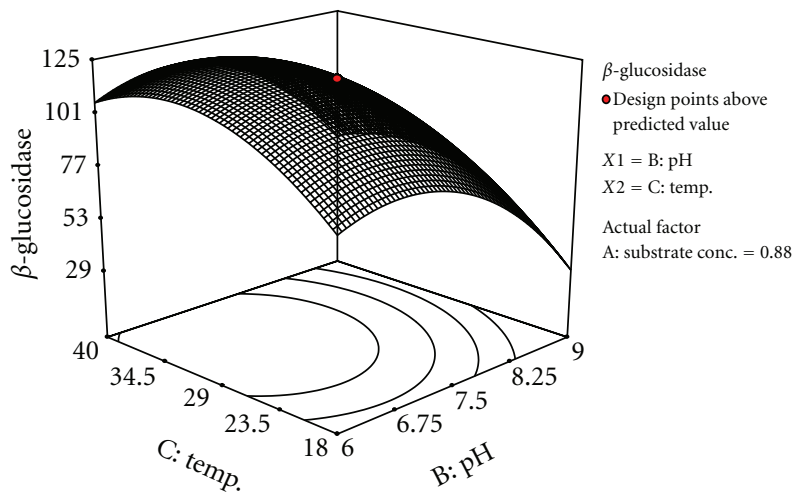

(c)

FIGURE 2: (a) Response surface plot showing the effect of $\mathrm{pH}$ and substrate concentration on $\beta$-glucosidase production in SSF with other variables constant at middle level. (b) Response surface plot showing the effect of temperature and substrate concentration on $\beta$-glucosidase production in SSF with other variables constant at middle level. (c) Response surface plots showing the effect of temperature and pH on $\beta$-glucosidase production in SSF with other variables constant at middle level.

TABLE 4: Analysis of variance for endoglucanase production.

\begin{tabular}{|c|c|c|c|c|c|c|}
\hline Source & Sum of squares & $\mathrm{df}$ & Mean square & $F$ value & $P$ value & Prob $>F$ \\
\hline Model & 443015 & 9 & 49223.9 & 39.1325 & $<.0001$ & significant \\
\hline A-sub. conc & 103453 & 1 & 103453 & 82.2436 & $<.0001$ & \\
\hline B-pH & 54184.2 & 1 & 54184.2 & 43.0758 & $<.0001$ & \\
\hline C-temp & 2071.07 & 1 & 2071.07 & 1.64648 & .2284 & \\
\hline $\mathrm{AB}$ & 7812.5 & 1 & 7812.5 & 6.21085 & .0319 & \\
\hline $\mathrm{AC}$ & 0 & 1 & 0 & 0 & 1 & \\
\hline $\mathrm{BC}$ & 312.5 & 1 & 312.5 & 0.24843 & .629 & \\
\hline$A^{2}$ & 26670.3 & 1 & 26670.3 & 21.2026 & .001 & \\
\hline$B^{2}$ & 201171 & 1 & 201171 & 159.929 & $<.0001$ & \\
\hline$C^{2}$ & 88522.3 & 1 & 88522.3 & 70.3743 & $<.0001$ & \\
\hline
\end{tabular}

$\mathrm{R}^{2}-0.9724$, Adj $\mathrm{R}^{2} 0.9475$, Pred $\mathrm{R}^{2}-0.7892$, C.V. $\%-12.39$.

of water hyacinth for highest production of $\beta$-glucosidase and endoglucanase, by Rhizopus oryzae MTCC 9642 under optimal conditions was carried out for verification of the optimization. Maximum $\beta$-glucosidase and endoglucanase production was $137.32 \mathrm{U} / \mathrm{mL}$ and $495 \mathrm{U} / \mathrm{mL}$ which was $3.22 \%$ and $0.32 \%$ less than the predicted value, respectively. This discrepancy was probably due to the slight variation in experimental conditions. In unoptimized condition, the production of $\beta$-glucosidase and endoglucanase was $16.66 \mathrm{U} / \mathrm{mL}$ and $25 \mathrm{U} / \mathrm{mL}$, respectively, (run no.10 Table 2 ). After optimization, the maximum production of $\beta$-glucosidase and endoglucanase became $137.32 \mathrm{U}$ and $495 \mathrm{U} / \mathrm{mL}$ leading to a respective 8.24 - and 19.8 -fold increase in the cocktail enzyme production. 


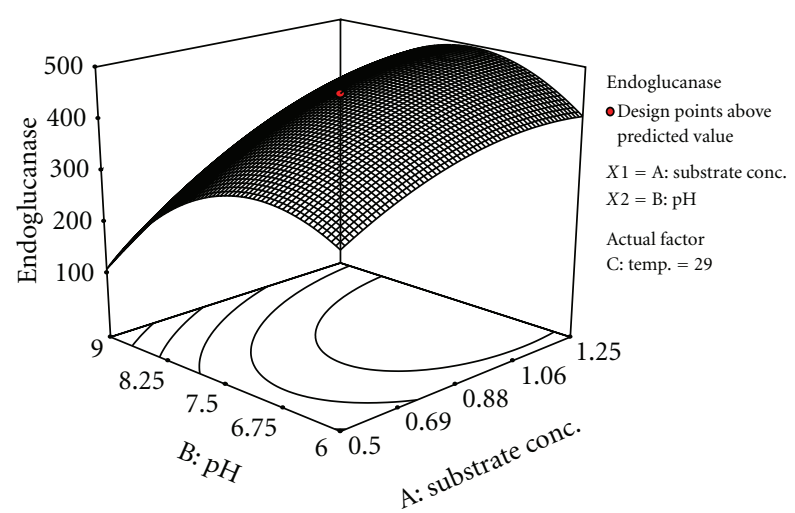

(a)

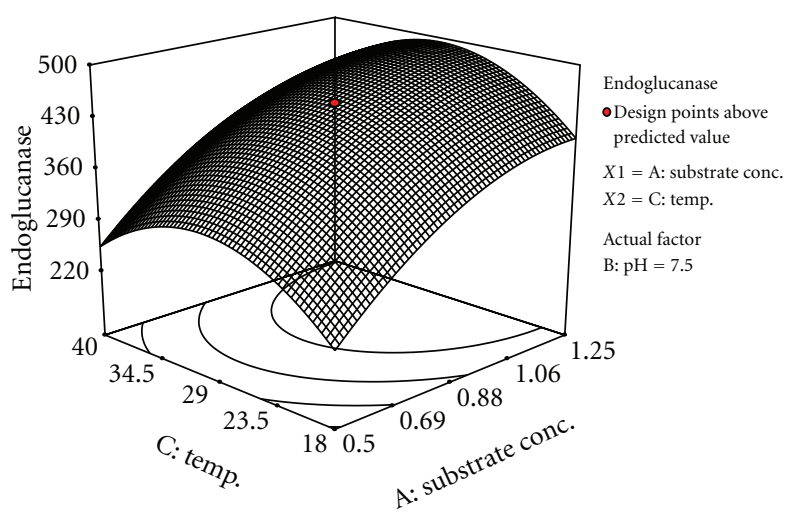

(b)

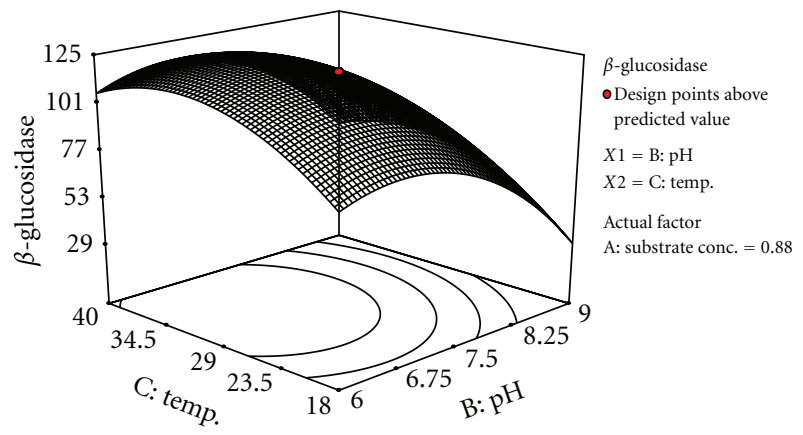

(c)

FIGURE 3: (a) Response surface plot showing the effect of $\mathrm{pH}$ and substrate concentration on endoglucanase production in SSF with other variables constant at middle level. (b) Response surface plots showing the effect of substrate concentration and temperature on endoglucanase production in SSF with other variables constant at middle level. (c) Response surface plots showing the effect of pH and temperature on endoglucanase production in SSF with other variables constant at middle level.

\section{Conclusion}

Although the effects of process parameters like substrate pretreatment, substrate concentration, initial medium $\mathrm{pH}$, mode of inoculation, and incubation temperature on cellulase production were investigated by many investigators $[7,17,25]$, but optimization rarely involved RSM of the parameters and therefore failed to evaluate multiple parameters at a time. In the present strain, optimization of parameters for simultaneous production of $\beta$-glucosidase and endoglucanase from SSF of water hyacinth showed that maximum $\beta$-glucosidase production of $137.32 \mathrm{U} / \mathrm{mL}$ was achieved at a substrate concentration of $1.25 \%, \mathrm{pH} 6.66$, and temperature $32.09^{\circ} \mathrm{C}$, whereas highest amount $(495 \mathrm{U} / \mathrm{mL})$ of endoglucanase was obtained at a substrate concentration of $1.23 \%, \mathrm{pH} 7.29$, and temperature $29.93^{\circ} \mathrm{C}$, which was quite a large amount in comparison to the other reports available $[5,9,11,26]$.This could be effectively used for bulk production of these enzymes at a nominal cost.

\section{Acknowledgment}

The authors wish to thank the Department of Science and Technology (DST), West Bengal, India, for the financial assistance.

\section{References}

[1] M. P. Coughlan, "The properties of fungal and bacterial cellulases with comment on their production and application," Biotechnology Genetic Engineering Review, vol. 3, pp. 39-109, 1985.

[2] M. K. Bhat, "Cellulases and related enzymes in biotechnology," Biotechnology Advances, vol. 18, no. 5, pp. 355-383, 2000.

[3] G. Narasimha, A. Sridevi, B. Viswanath, Ch. M. Subhosh, and B. R. Reddy, "Nutrient effects on production of cellulolytic enzymes by Aspergillus niger," African Journal of Biotechnology, vol. 5, no. 5, pp. 472-476, 2006.

[4] R. K. Sukumaran, R. R. Singhania, G. M. Mathew, and A. Pandey, "Cellulase production using biomass feed stock and its application in lignocellulose saccharification for bio-ethanol production," Renewable Energy, vol. 34, no. 2, pp. 421-424, 2009.

[5] M. Camassola and A. J. P. Dillon, "Cellulases and xylanases production by Penicillium echinulatum grown on sugar cane bagasse in solid-state fermentation," Applied Biochemistry and Biotechnology, vol. 162, pp. 1889-1900, 2010.

[6] A. Singh, N. Singh, and N. R. Bishnoi, "Production of cellulases by aspergillus heteromorphus from wheat straw under submerged fermentation," International Journal of Civil and Environmental Engineering, vol. 1, pp. 23-26, 2009.

[7] P. B. Acharya, D. K. Acharya, and H. A. Modi, "Optimization for cellulase production by Aspergillus niger using saw dust as 
substrate," African Journal of Biotechnology, vol. 7, pp. 41474152, 2008.

[8] M. A. Milala, A. Shugaba, A. Gidado et al., "Studies on the use of agricultural wastes for cellulase enzyme production by Aspergillus niger," Research Journal of Agricultural Biological Science, vol. 1, pp. 325-328, 2005.

[9] P. Deshpande, S. Nair, and S. Khedkar, "Water hyacinth as carbon source for the production of cellulase by Trichoderma reesei," Applied Biochemistry and Biotechnology, vol. 158, no. 3, pp. 552-560, 2009.

[10] S. K. Deshpande, M. G. Bhotmange, T. Chakrabarti, and P. N. Shastri, "Production of cellulase and xylanase by Trichoderma reesei (QM 9414 mutant), Aspergillus niger and mixed culture by solid state fermentation (SSF) of water hyacinth (Eichhornia crassipes)," Indian Journal of Chemical Technology, vol. 15, no. 5, pp. 449-456, 2008.

[11] A. M. S. Ismail, M. A. Abdel-Naby, and A. F. Abdel-Fattah, "Utilization of water hyacinth cellulose for production of cellobiase-rich preparation by Aspergillus niger 1," Microbios, vol. 83, no. 336, pp. 191-198, 1995.

[12] S. Mukhopadhyay, P. S. Mukherjee, and N. C. Chatterjee, "Optimization of enzymatic hydrolysis of water hyacinth by Trichoderma reesei vis-a-vis production of fermentable sugars," Acta Alimentaria, vol. 37, no. 3, pp. 367-377, 2008.

[13] M. A. Bezerra, R. E. Santelli, E. P. Oliveira, L. S. Villar, and L. A. Escaleira, "Response surface methodology (RSM) as a tool for optimization in analytical chemistry," Talanta, vol. 76, no. 5, pp. 965-977, 2008.

[14] V. Deepak, K. Kalishwaralal, S. Ramkumarpandian, S. V. Babu, S. R. Senthilkumar, and G. Sangiliyandi, "Optimization of media composition for Nattokinase production by Bacillus subtilis response surface methodology," Bioresource Technology, vol. 99, no. 17, pp. 8170-8174, 2008.

[15] P. Joni, S. Shyuuhei, Naoyuki, A. Okuda, and E. Y. Park, "Response of cellulase activity in $\mathrm{pH}$-controlled cultures of the filamentous fungus acremonium cellulolyticus," Applied Biochemistry and Biotechnology, vol. 162, no. 1, pp. 52-61, 2010.

[16] R. R. Singhania, R. K. Sukumaran, and A. Pandey, "Improved cellulase production by Trichoderma reesei RUT C30 under SSF through process optimization," Applied Biochemistry Biotechnology, vol. 142, pp. 60-70, 2010.

[17] M. Karmakar and R. R. Ray, "Extra cellular endoglucanase production by Rhizopus oryzae in solid and liquid state fermentation of agro wastes," Asian Journal of Biotechnology, vol. 2, pp. 27-36, 2010a.

[18] M. Karmakar and R. R. Ray, "Characterization of extra cellular thermostable endoglucanase from Rhizopus oryzae response surface methodology," Research and Review in Biosciences, vol. 4, pp. 50-55, 2010b.

[19] P. Bernfeld, "Amylases $\alpha$ and $\beta$," Methods of Enzymology, vol. 1, pp. 149-150, 1955.

[20] G. E. P. Box, W. G. Hunter, and J. S. Hunter, Statistics for Experimenters, John Wiley \& Sons, New York, NY, USA, 1978.

[21] P. D. Haaland, "Separating signals from the noise," in Experimental Design in Biotechnology, pp. 61-83, Marcel Dekker, New York, NY, USA, 1989.

[22] G. E. P. Box and D. R. Cox, "An analysis of transformations," Royal Statistical Society. Series B., vol. 26, no. 2, pp. 211-246, 1964.

[23] R. Hamsaveni, S. G. Prapulla, and S. Divakar, "Response surface methodological approach for the synthesis of isobutyl isobutyrate," Process Biochemistry, vol. 36, no. 11, pp. 1103 1109, 2001.
[24] Design expert 7.1.5 users guide manual.

[25] A. M. de Castro, K. C. Nascimento Rodrigues Pedro, J. Cunha da Cruz, M. Costa Ferreira, S. Gomes Ferreira Leite, and N. Pereira, "Cellulases from Penicillium funiculosum production, properties and application to cellulose hydrolysis," Applied Biochemistry Biotechnology, vol. 162, pp. 2111-2122, 2010.

[26] A. Kumar, L. K. Singh, and S. Ghosh, "Bioconversion of lignocellulosic fraction of water-hyacinth (Eichhornia crassipes) hemicellulose acid hydrolysate to ethanol by Pichia stipitis," Bioresource Technology, vol. 100, no. 13, pp. 3293-3297, 2009. 

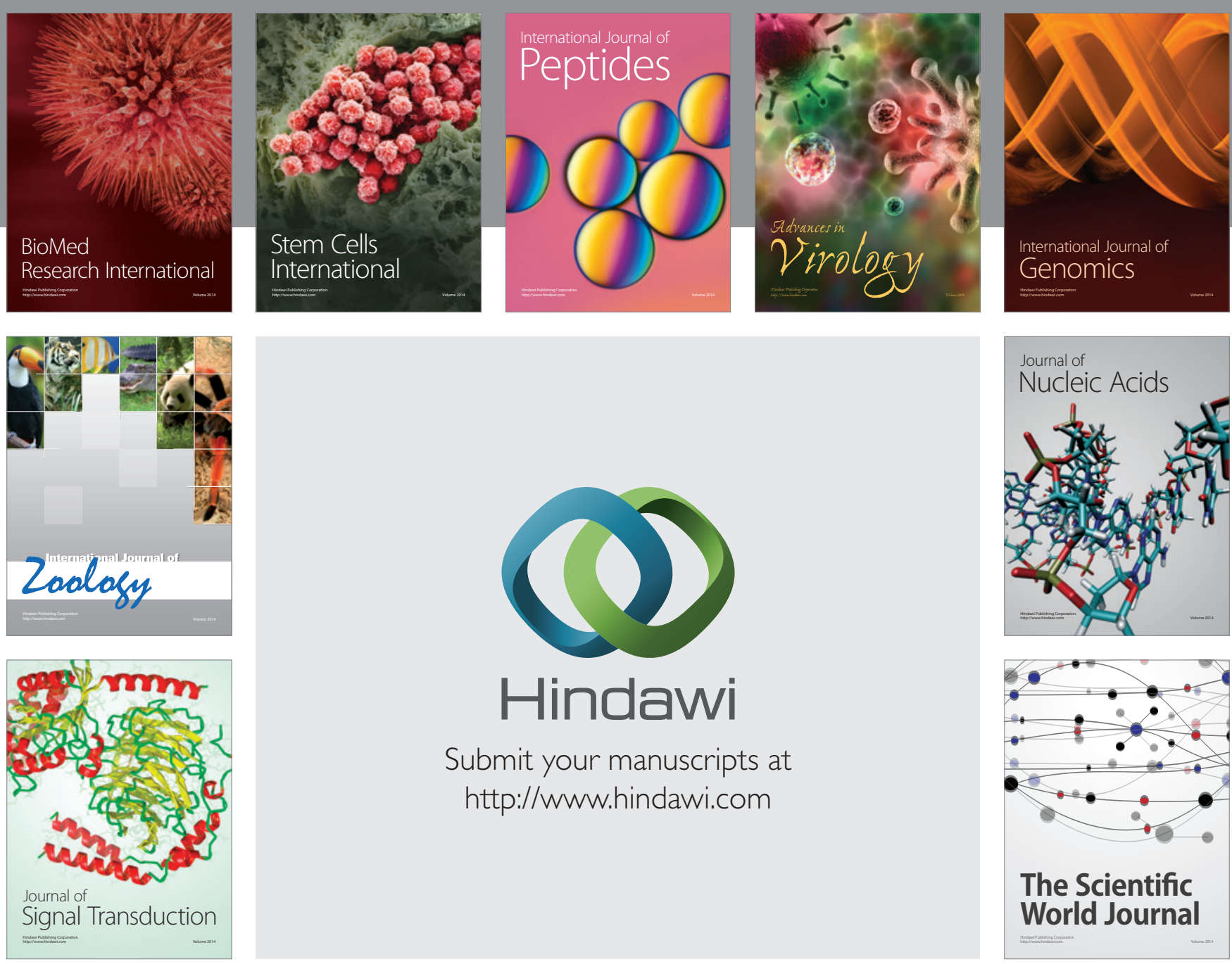

Submit your manuscripts at

http://www.hindawi.com
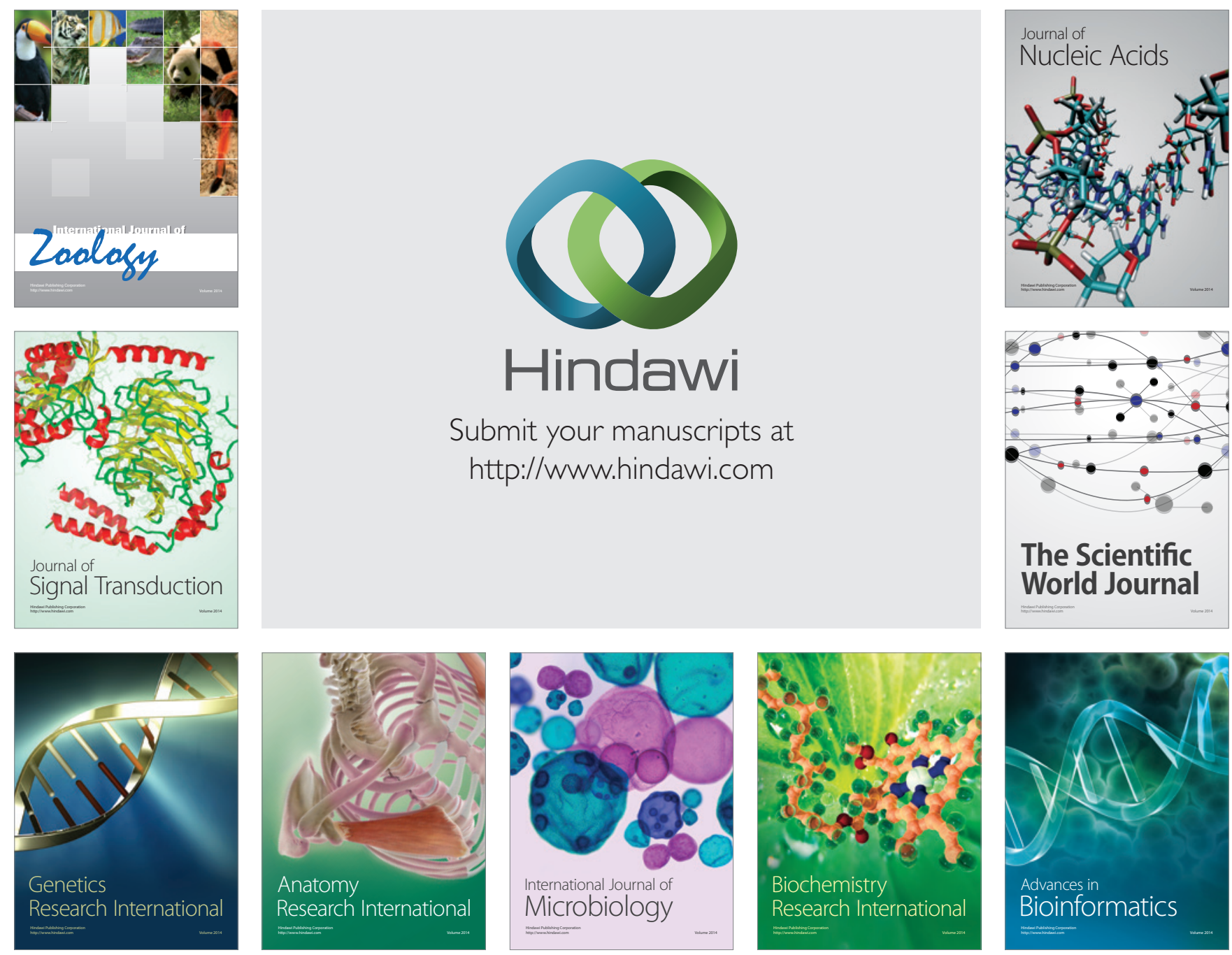

The Scientific World Journal
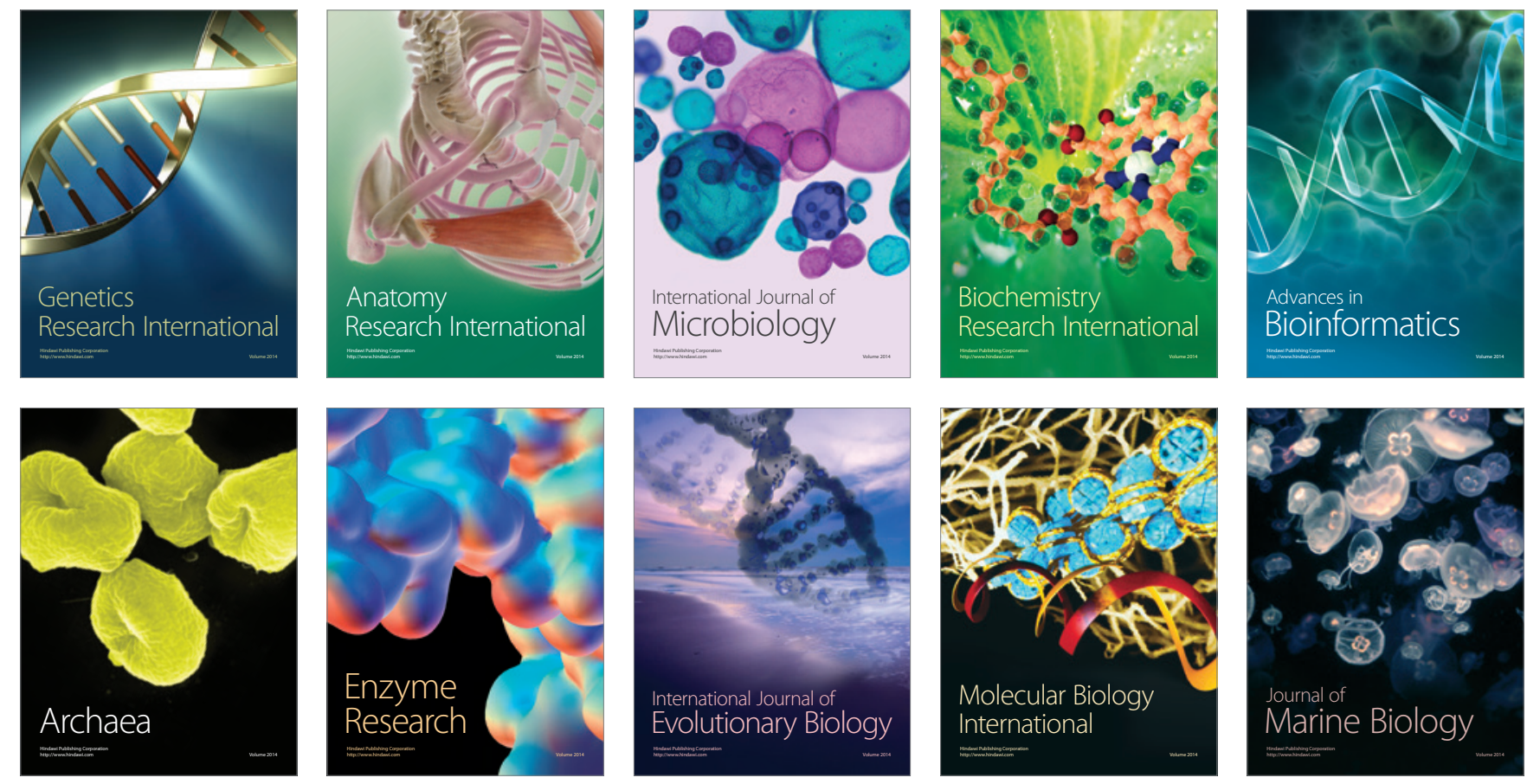